\title{
Aplikasi Pengingat Dan Pendataan Kenaikan Golongan Gaji Berbasis Web Menggunakan Metode White Box Testing dan Black Box Testing
}

\author{
Firman, Fauziah, Ratih Titi Komalasari \\ Universitas Nasional, Jakarta \\ email:imanfirman020@gmail.com¹,fauziah@civitas.unas.ac.id², ukhuwahku01@gmail.com³
}

\begin{abstract}
Abstrak
Universitas Nasional sebagai lembaga pendidikan memiliki sejumlah dosen dan karyawan yang dapat mengajukan diri agar mendapat kenaikan pangkat dan kenaikan gaji secara berkala. Biasanya, kenaikan golongan akan dibarengi oleh kenaikan gaji karyawan. Saat ini, pengajuan kenaikan tersebut masih manual dimana dosen dan karyawan harus memiliki catatan tambahan tersendiri mengenai kenaikan golongan dan gaji mereka. Hal tersebut karena belum terdapat sistem pendataan ataupun pengingat yang membantu mereka dalam melakukan pengajuan tersebut. Apabila dosen dan karyawan tersebut memiliki banyak kesibukan, maka hak kenaikan golongan dan gaji mereka dapat terabaikan. Penelitian ini untuk mengembangkan aplikasi pendataan dan pengingat bagi karyawan di Universitas Nasional sehingga mereka dapat melakukan pengajuan kenaikan golongan dan gaji tepat waktu. Aplikasi tersebut dikembangkan dengan memanfaatkan tool Unified Modelling Language (UML) serta bahasa pemprograman PHP. Hasil dari penelitian ini adalah tersedianya aplikasi pendataan dan pengingat, yang dapat membantu dosen dan karyawan di Universitas Nasional dalam mengajukan kenaikan golongan dan gajinya. Hasil pengujian black box setiap menu yang ada pada aplikasi berjalan sesuai dengan fungsinya, pada hasil pengujian white box menghasilkan nilai Cyclomatic Complexity $=30$, Region $=30$ Indenpenden Path $=30$, maka ditarik kesimpulan bahwa alur logika system aplikasi pengingat untuk kenaikan golongan dan gaji berbasis web ini sudah benar dan sesuai dan tidak ada error dalam aplikasi yang dirancang.

Kata kunci : aplikasi pengingat, kenaikan pangkat, kenaikan gaji, aplikasi berbasis web.
\end{abstract}

\section{Abstract}

The Univeritas Nasional as an educational institution has a number of lecturers and employees who can apply for promotion and salary increase on a regular basis. Usually, a promotion will be accompanied by an increase in the employee's salary. Currently, the application for the increase is still manual where lecturers and employees must have their own additional records regarding their promotion and salary increase. This is because there is no data collection or reminder system to assist them in making the submission. If the lecturers and employees are busy, their right to promotion and salary increase can be ignored. This research is to develop a data collection and reminder application for employees at the National University, so that they can apply for promotion and salary increase on time. The application was developed using the Unified Modeling Language (UML) tool and the PHP programming language. The result of this research is the availability of data collection and reminder applications, which can assist lecturers and employees at the National University in applying for promotion and salary increase. Black box test results of each menu in the application runs in accordance with its function, on the test results white box generates the value of Cyclomatic Complexity $=30$, Region $=30$ Independent Path $=30$, then it is concluded that the logic flow of the application system reminder for class increase and web-based salary is correct and appropriate and there are no errors in the designed application.

Keywords: reminder application, promotion, salary increase, web based application. 
Salah satu hak dari dosen dan karyawan di Universitas Nasional adalah mengajukan kenaikan golongan dan gaji. Untuk melakukan hal tersebut, terdapat persyaratan yang harus dipenuhi oleh dosen dan karyawan yang bersangkutan. Jika seluruh persyaratan telah lengkap, mereka dapat mengajukan kenaikan tersebut melalui Ketua Program Studi atau Kepala Bagian untuk selanjutnya diteruskan ke Biro Sumber Daya Manusia (BSDM) [1]. Salah satu permasalahan yang sering terjadi pada proses tersebut adalah dosen dan karyawan kadang lupa untuk mengajukan kenaikan golongan dan gaji tersebut. Salah satu penyebabnya yaitu kesibukan kerja sehingga mereka lupa untuk mengurus kenaikan tersebut. Jika terjadi hal demikian, tentunya akan merugikan dosen dan karyawan yang bersangkutan, karena hak kenaikan golongan dan gaji mereka terhambat. Akibatnya, tingkat kesejahteraan dosen dan karyawan yang bersangkutan akan terganggu, apalagi jika penghasilan utama mereka dari Universitas Nasional. Selain itu, jika terjadi keterlambatan kenaikan golongan dan gaji, biasanya akan berpengaruh pada kinerja dan prestasi dosen dan karyawan yang bersangkutan [2]. Disisi lain, proses pengajuan kenaikan golongan dan gaji di Universitas Nasional memang masih dilakukan secara manual yaitu dengan melihat data karyawan, SK kenaikan sebelumnya, buku kuning dan peraturan tentang kenaikan golongan dan gaji. Hal tersebut tentunya memerlukan waktu yang lama dan rawan untuk terjadinya kesalahan data.

Oleh karena itu, penelitian ini dilakukan untuk mengembangkan aplikasi pendataan dan pengingat bagi dosen dan karyawan di Universitas Nasional. Aplikasi ini dikembangkan dan disesuaikan dengan kebutuhan pengguna yaitu bagian Biro Sumber Daya Manusia Universitas Nasional. Aplikasi yang dihasilkan dalam penelitian ini diharapkan dapat membantu dosen dan karyawan dalam melakukan pengajuan kenaikan golongan dan gaji mereka. Berdasarkan latar belakang, maka rumusan masalah dalam penelitian ini adalah bagaimanakah rancangan aplikasi pendataan dan pengingat kenaikan golongan dan gaji bagi dosen dan karyawan di Universitas Nasional?. Saat ini proses kenaikan pangkat atau golongan berkala/ regular masih manual dengan cara pengajuan dari Biro Sumber Daya Manusia ke unit kerja dengan memberikan from DP3 untuk di ketahui dan diberikan penilaian oleh pimpinan terkait. Adapun tujuan penelitian ini adalah merancang aplikasi pendataan dan pengingat kenaikan golongan dan gaji di Universitas Nasional yang dapat membantu dosen dan karyawan dalam melakukan pengajuan kenaikan golongan dan gaji secara berkala.

\section{METODE PENELITIAN}

Ada beberapa tahap yang peneliti lakukan untuk menyelesaikan permasalahan dalam penelitian ini. Tahapan tersebut dapat dilihat pada Gambar 1.

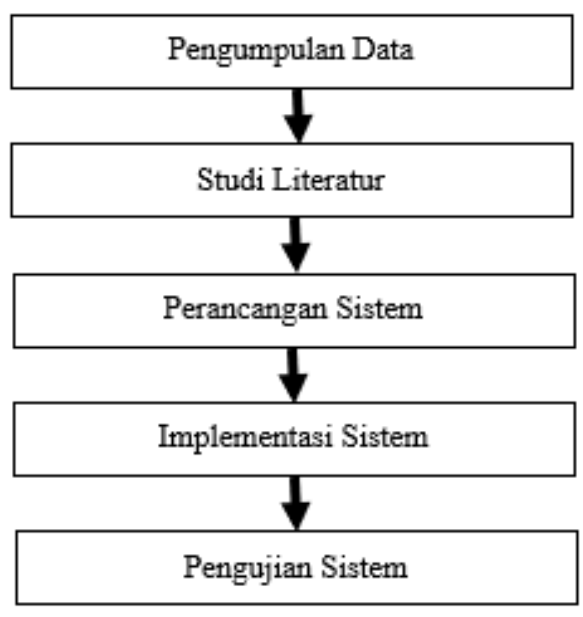

Gambar 1. Tahapan Penelitian

Gambar 1 merupaka tahapan penelitian yang dilakukan terdiri dari proses pengumpulan data sampai dengan pengujian aplikasi yang didesain.

\subsection{Pengumpulan Data}

Peneliti memulai penelitian ini dengan mengumpulkan data yang dapat mendukung penyelesaian permasalahan dalam penelitian ini. Pengumpulan data dilakukan dengan melakukan wawancara langsung dengan pihak Universitas Nasional yang terlibat dalam proses kenaikan 
golongan dan gaji antara lain dosen dan karyawan, ketua program studi dan kepala biro serta bagian Biro Sumber Daya Manusia Universitas Nasional. Selain itu, peneliti juga melakukan pengamatan terhadap proses berjalan dalam pengajuan kenaikan golongan dan gaji di Universitas Nasional.

\subsection{Studi Literatur}

Langkah berikutnya yaitu peneliti melakukan studi pustaka dengan mencari penelitian serupa yang pernah dilakukan oleh para peneliti sebelumnya. Dari studi literatur ini, peneliti memperoleh informasi bahwa sudah terdapat beberapa penelitian yang membahas masalah yang sama seperti kepegawaian dan kenaikan pangkat. Penelitian tersebut antara lain: Aplikasi Sistem Arsip Kepegawaian Untuk Keperluan Kenaikan Pangkat Dengan Pengingat Berbasis SMS Gateway (Studi Kasus Kantor Kecamatan Bojongloa Kidul Bandung) [3], Aplikasi Pendataan Dan Pengingat Kenaikan Gaji Serta Kenaikan Golongan Berbasis SMS Gateway [4], Sistem Informasi Kenaikan Pangkat Dan Kenaikan Gaji Berkala Pegawai [5], Sistem Aplikasi Pengingat Informasi Kepegawaian (APIK) Untuk Percepatan Pengusulan Kenaikan Pangkat Tepat Waktu dan Tepat Sasaran di Pemerintah Kabupaten Banjarnegara [6] dan Rancang Bangun Sistem Informasi Kenaikan Pangkat Pada Kantor Gubernur Provinsi Nusa Tenggara Barat [7].

Hasil studi literatur ini memberikan gambaran kepada peneliti mengenai hal-hal yang mungkin diterapkan dalam aplikasi pada penelitian ini. Fokus peneliti pada penelitian ini adalah mengembangkan aplikasi berbasis web dengan Bahasa pemprograman PHP sehingga mudah dan cepat dalam prosesnya.

\subsection{Perancangan Aplikasi}

Setelah mendapatkan gambaran dari berbagai penelitian terdahulu, selanjutnya peneliti melakukan perancangan sistem untuk menggambarkan sistem secara keseluruhan. Pada langkah ini, peneliti menggunakan tools Unified Modelling Language (UML) yang memiliki fitur lengkap dan mudah dalam perancangannya [8]. Lebih detail, peneliti menggunakan diagram use case yang merupakan bagian dari UML [9]

\subsection{Implementasi Aplikasi}

Sesuai yang telah dibahas pada subbab sebelumnya bahwa untuk mengimplentasikan aplikasi pendataan dan pengingan kenaikan golongan ini, peneliti menggunakan Bahasa pemprograman PHP. Bahasa tersebut telah digunakan secara luas khususnya untuk berbagai aplikasi berbasis web. Implementasi aplikasi ini disesuaikan dengan kebutuhan Bagian Biro Sumber Daya Manusia Universitas Nasional yang peneliti peroleh dari hasil wawancara dan pengamatan langsung.

\subsection{Pengujian Aplikasi}

Untuk memastikan aplikasi berjalan sesuai dengan yang diharapkan, peneliti melakukan pengujian dengan metode black box. Tujuannya adalah untuk mengetahui apakah fungsionalitas aplikasi telah berjalan dan tidak terdapat error atau bug didalamnya [10].

\section{HASIL}

\subsection{Perancangan Aplikasi}

\section{a. Diagram Use Case}

Diagram use case dibawah ini menggambarkan aktor yang terlibat dalam aplikasi pendataan dan pengingat kenaikan golongan dan gaji yaitu admin. Admin bisa login, memasukan data pegawai, mengubah data pegawai, memasukan data gaji, memasukan kenaikan golongan dan mencetak laporan dapat dilihat pada Gambar 2. 


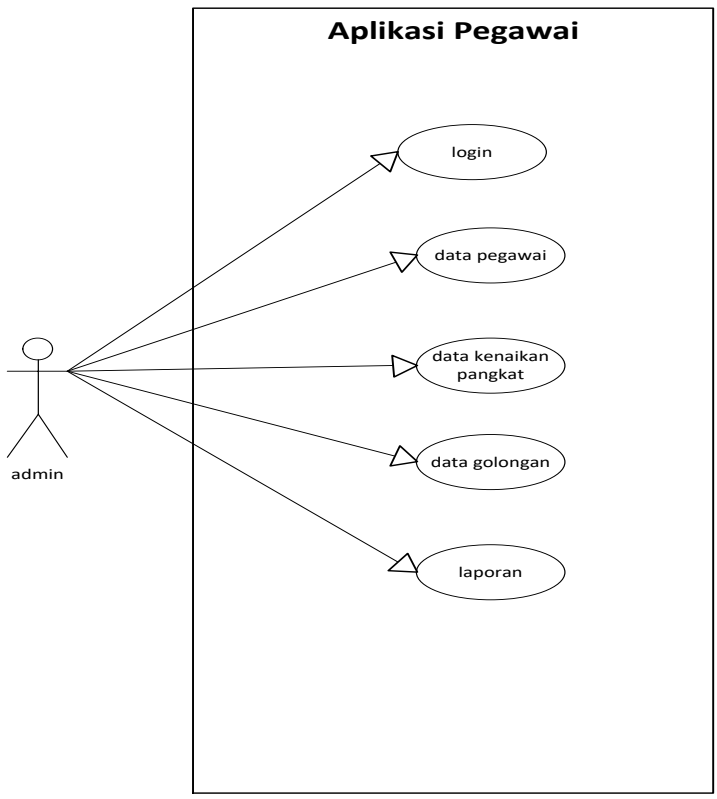

Gambar 2. Use Case Aplikasi

Gambar 2 menjelaskan tentang use case aplikasi mulai dari menu login dan melakukan proses pembuatan laporan

\section{b. Rancangan Database}

Gambar 3 memperlihatkan relasi antara 53able didalam database aplikasi pengingat dalam penelitian ini, dimana ada terdapat 53able pegawai, gaji, tanggal_bergabung, admin dan 53able golongan.

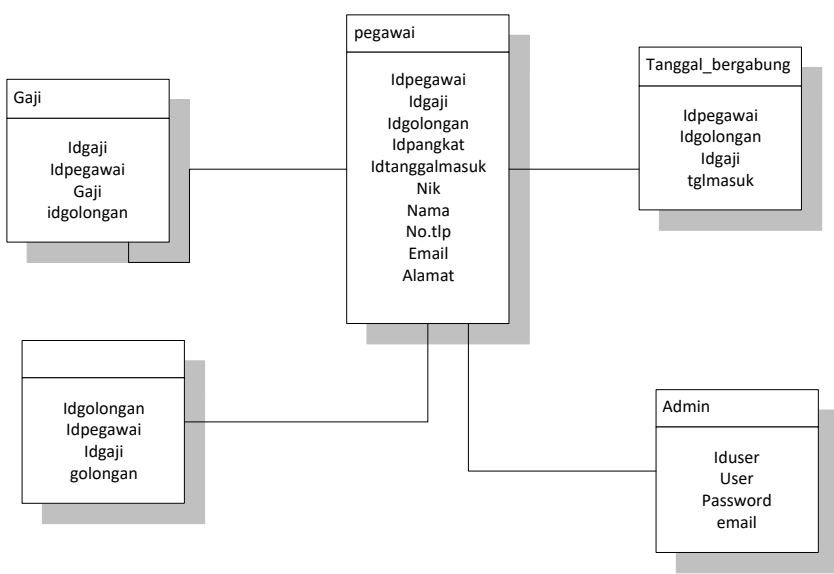

Gambar 3. Rancangan Basis data

Gambar 3 merupakan rancangan database yang digunakan dalam pembuatan aplikasi yang terdiri dari beberapa tabel yang ada kaitannya dengan pegawai.
Pada tahapan desain arsitektur menu, terlihat bahwa saat admin login kedalam aplikasi, maka akan langsung diarahkan ke halaman dashboard. Selanjutnya terdapat menu data pegawai, gaji, lampiran dan laporan yang dapat diakses oleh admin untuk mengoprasikan aplikasi pengingat kenaikan golongan dan gaji ini. Gambaran umumnya seperti pada Gambar 4:

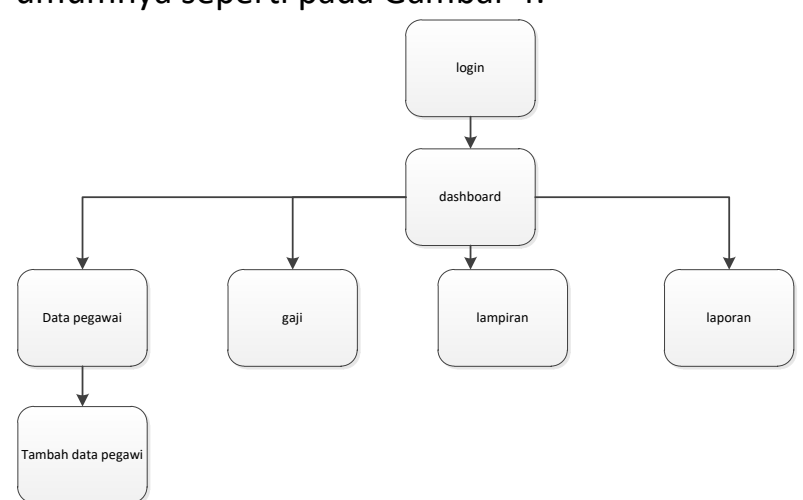

Gambar 4. Desain Arsitektur Menu Gambar 4 merupakan desain arsitektur menu yang ada pada aplikasi mulai dari menu login sampai menu laporan

\subsection{Implementasi Aplikasi}

Tahapan implementasi peneliti lakukan setelah memastikan rancangan aplikasi pada subbab sebelumnya telah sesuai dengan kebutuhan pengguna, yaitu bagian Biro Sumber Daya Manusia Universitas Nasional. Hasil implementasi aplikasi pada penelitian ini menghasilkan antarmuka pengguna. Adapun desain antarmuka untuk aplikasi pengingat berbasis web ini adalah sebagai berikut:

a. Halaman Login.

Tampilan Halaman login aplikasi pada penelitian ini digunakan oleh admin untuk masuk dan memulai proses pengelolaan datanya. Untuk masuk admin harus memasukkan data username dan diikuti oleh data password. Tampilannya sesuai Gambar 5:

\section{c. Desain Arsitektur Menu}




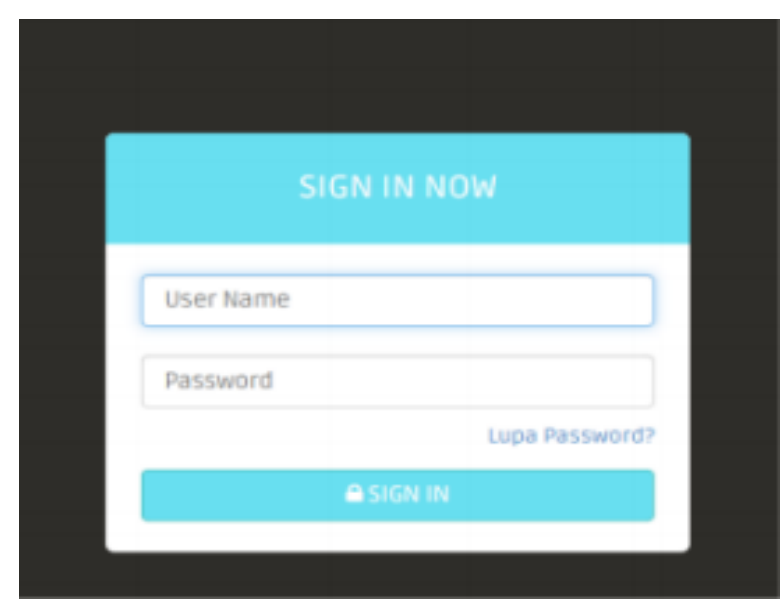

Gambar 5. Halaman Login

\section{b. Halaman Dashboard}

Dashboard aplikasi pada penelitian ini akan tampil saat pertama kali user masuk ke dalamnya. Tampilan halaman ini sesuai dengan Gambar 6:

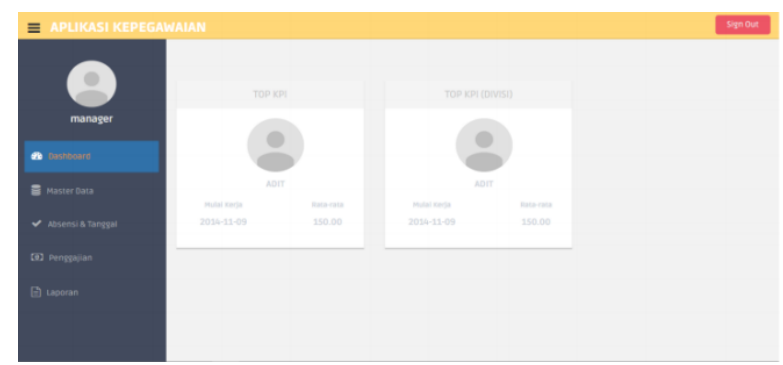

Gambar 6. Dashboard Aplikasi Pengingat

c. Halaman Pegawai

Tampilan antarmuka data pegawai dapat diakses oleh admin dengan mengklik menu Data Pegawai. Halaman tersebut berisi detail data pegawai yang ada. Ada beberapa aksi yang dapat dilakukan oleh admin seperti menambah, mengubah dan menghapus datanya. Antarmuka halaman ini sesuai Gambar 7:

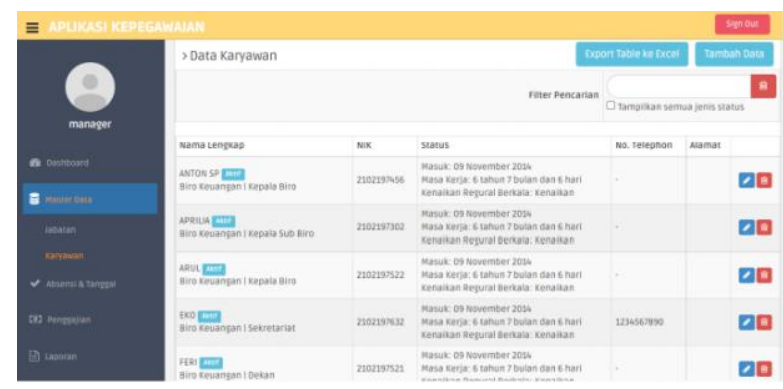

Gambar 7. Antarmuka Data Pegawai/Karyawan
Tampilan form tambah pegawai yaitu untuk menambah data pegawai dengan menginputkannya kedalam aplikasi seperti Gambar 8:

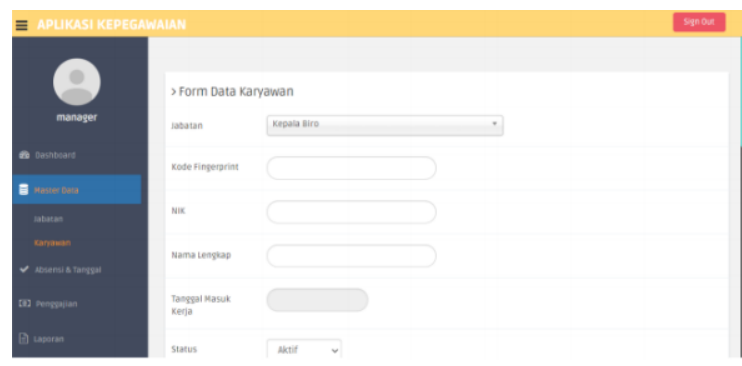

Gambar 8. Halaman Form Tambah Pegawai

d. Halaman Penggajian

Tampilan ini berisi data gaji pegawai yang dapat diakses oleh admin dengan mengklik menu Penggajian seperti pada Gambar 9:

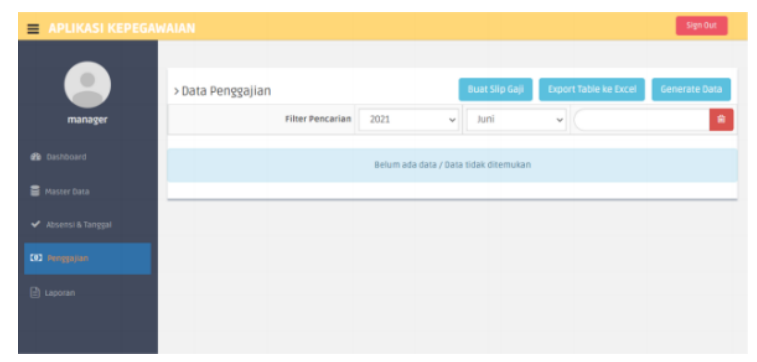

Gambar 9. Tampilan Data Gaji

e. Halaman laporan

Untuk mengakses laporan kepegawaian dalam aplikasi ini, admin dapat mengklik menu Laporan seperti pada Gambar 10:

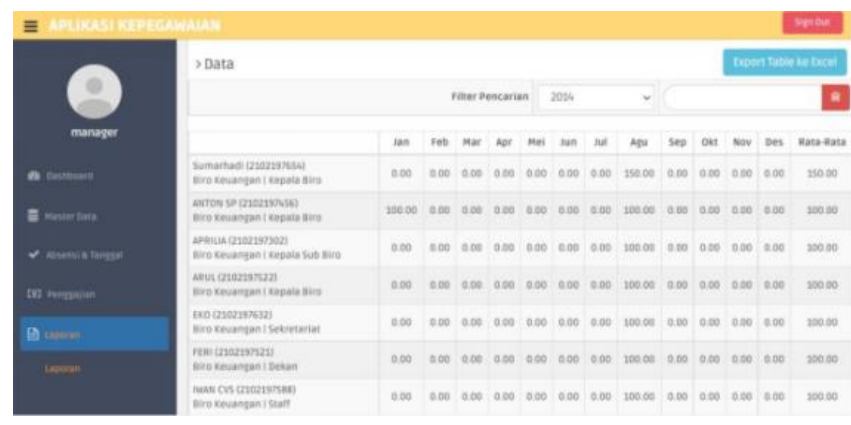

Gambar 10. Tampilan Halaman Laporan 


\subsection{Pengujian Aplikasi}

Dalam menguji aplikasi ini, peneliti menggunakan 2 metode yaitu White Box dan Black Box. Kedua pengujian tersebut dilakukan untuk memastikan seluruh logika dan fungsi yang ada pada aplikasi dapat berjalan dengan baik.

\subsubsection{Metode White Box}

Langkah pertama yang peneliti lakukan pada tahap ini yaitu menguji menggunakan metode white box aplikasi dengan memilih jalur logika penting yang ada. Beberapa logika tersebut antara lain:

\section{a. Proses Login}

Login menjadi salah satu proses penting dalam aplikasi ini. Prosesnya seperti pada Gambar 11:

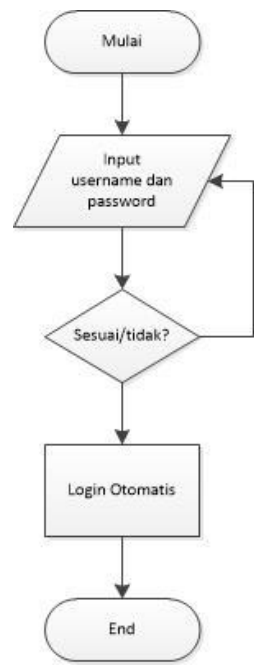

Gambar 11. Proses Login

Hasil pengujian ini menunjukkan bahwa fungsi aplikasi berjalan sesuai logika yang ada. Jika pengguna memasukkan data username dan password yang benar, maka secara otomatis sistem menerima dan mengarahkan admin ke dashboard. Tetapi jika data salah, maka sistem akan memberikan peringatan dan meminta pengguna untuk mengisi data secara benar.

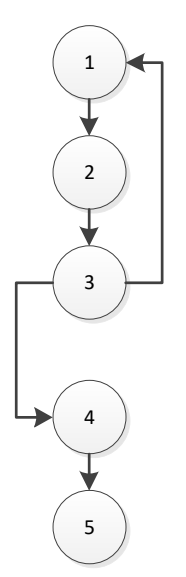

\section{Gambar 12 Flowchart Node Login}

Dari gambar 12 merupakan Cyclomatic dari flowchart node login dimana proses login mempunyai $5(\mathrm{~N})$ node dan 5 (E)edge. Maka untuk Path :

$\mathrm{V}(\mathrm{G})=\mathrm{E}-\mathrm{N}+2$

$=5-5+2$

$=2$

Maka jumlah Path sebanyak 2.

b. Proses Pengelolaan Data

Proses dan logika dalam pengelolaan data yaitu pegawai, gaji, lampiran dan laporan seperti pada Gambar 12:

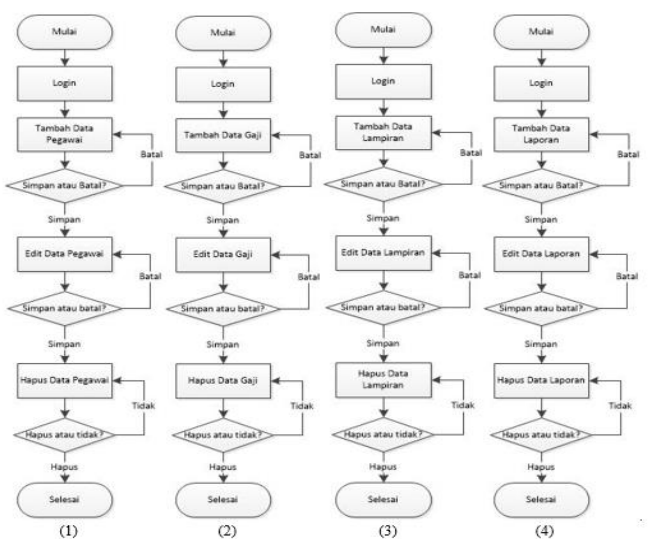

Gambar 12. Proses Pengelolaan Data Pegawai

(1), Gaji (2), Lampiran (3) dan Laporan (4)

Setelah dilakukan pengujian terhadap logika Pengelolaan Data Pegawai, Pengelolaan Data Gaji, Pengelolaan Data Lampiran dan Pengelolaan Data Laporan, didapatkan bahwa selutuh fungsi berjalan dengan baik sesuai alur yang ada.

c. Perhitungan Kompleksitas Cyclomatic

Dari flowchat pada gambar 12 mempunyai perhitungan kompleksitas Cyclomatic dalam 
jalur tiap note yang dapat dilihata pada gambar 13:

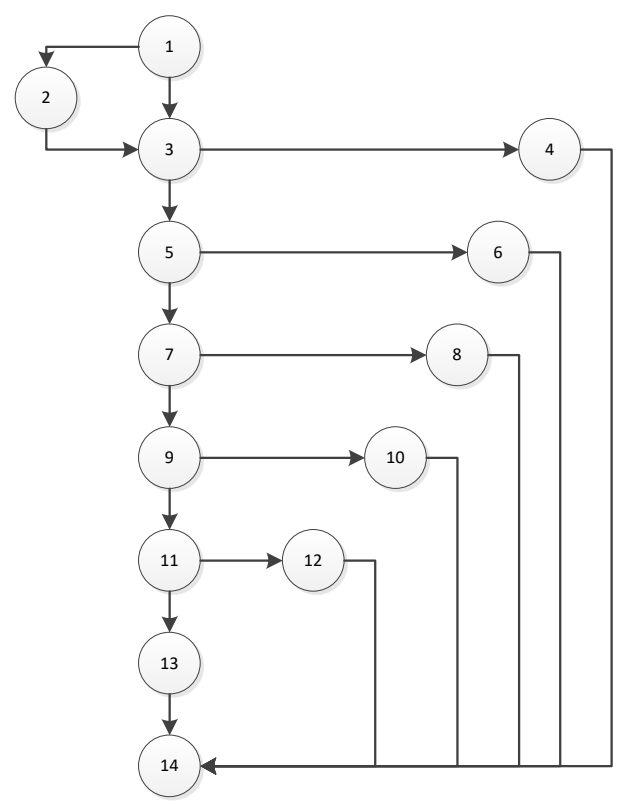

Gambar 13 Flowchart Note

Untuk menghitung kompleksitas cyclomatic menggunkan rumus :

$$
\begin{aligned}
& V(G)=E=N+2 \\
& =19-14+2 \\
& =7
\end{aligned}
$$

Keterangan

$\mathrm{E}=$ jumlah Busur atau link

$\mathrm{N}=$ Jumlah simpul

Untuk jalur independent dari flowchart mempunyai 7 path:

Path 1:1-2-3-5-7-9--11-13-14

Path 2:1-3-4-14

Path 3:1-3-5-6-14

Path 4:1-3-5-7-8-14

Path 5:1-3-5-7-910-14

Path 6: 1-3-5-7-9--11-12-14

Path 7: 1-3-5-7-9--11-13-14

Tabel 1. Rekapitulasi Hasil Whitebox Testing

\begin{tabular}{|l|c|c|c|}
\hline \multicolumn{1}{|c|}{ Flowchart } & $\begin{array}{c}\text { Cyclomotic } \\
\text { Complacity }\end{array}$ & Region (R) & $\begin{array}{c}\text { Indenpenden } \\
\text { Path }\end{array}$ \\
\hline 1.login & 2 & 2 & 2 \\
2.Data Pegawai & 7 & 7 & 7 \\
3.Gaji & 7 & 7 & 7 \\
4.Lampiran & 7 & 7 & 7 \\
5.Laporan & 7 & 7 & 7 \\
\hline Jumlah & 30 & 30 & 30 \\
\hline
\end{tabular}

http://ejournal.urindo.ac.id/index.php/TI
Pada table 1 diatas adalah hasil pengujian yang dan dapat hasil bernilai sama untuk jumlah Cyclomatic Complexity $=30$, Region $=30$ Indenpenden Path $=30$, maka ditarik kesimpulan bahwa alur logika system aplikasi pengingat untuk kenaikan golongan dan gaji berbasis web ini sudah benar dan sesuai.

\subsubsection{Metode Black Box}

Pengujian aplikasi dengan blackbox testing dari menu yang ada pada aplikasi dilakukan pengujian dengan mengklik dan memasukan username serta password yang dterdapat pada halaman login dengan memasukan username dapat password yang sesuai dengan database serta mencoba memasukan username dan

\begin{tabular}{|c|c|c|c|c|}
\hline No & Fungsionalitas & Perintah dan Masukan & Hasil & Status \\
\hline \multirow[t]{2}{*}{1} & Menu Login & $\begin{array}{l}\text { Admin memasukkan } \\
\text { username dan password } \\
\text { dengan benar }\end{array}$ & $\begin{array}{l}\text { Sistem mengarahkan admin ke halaman } \\
\text { dashboard }\end{array}$ & Sukses \\
\hline & & $\begin{array}{l}\text { Admin masukkan username } \\
\text { dan password dengan salah }\end{array}$ & $\begin{array}{l}\text { Sistem menampilkan notifikasi dan } \\
\text { tampilan form login }\end{array}$ & Sukses \\
\hline 2 & Menu Pegawai & $\begin{array}{l}\text { Admin mengklik menu } \\
\text { karyawan serta menambah, } \\
\text { mengubah atau menghapus } \\
\text { data karyawan }\end{array}$ & $\begin{array}{l}\text { Sistem akan menampilkan data pegawai } \\
\text { sesuai perintah dan masukan. }\end{array}$ & Sukses \\
\hline 3 & $\begin{array}{l}\text { Menu } \\
\text { Penggajian }\end{array}$ & $\begin{array}{l}\text { Admin mengklik menu } \\
\text { penggajan serta } \\
\text { menambah, mengubah } \\
\text { atau menghapus data gaji. }\end{array}$ & $\begin{array}{l}\text { Sistem akan menampilkan data } \\
\text { penggajian sesuai perintah dan masukan. }\end{array}$ & Sukses \\
\hline 4 & Menu Laporan & $\begin{array}{l}\text { Admin mengklik menu } \\
\text { laporan }\end{array}$ & $\begin{array}{l}\text { Sistem akan menampilkan data laporan } \\
\text { sesuai ada yang ada pada aplikasi }\end{array}$ & Sukses \\
\hline
\end{tabular}
password yang salah.

Tabel 1. Pengujian Blackbox Testing

\section{KESIMPULAN}

Setelah melakukan seluruh tahapan dalam penelitian ini, makan peneliti dapat menarik kesimpulan:

1. Aplikasi Pengingat untuk Kenaikan Golongan dan Gaji Berbasis Web Bagi Dosen dan Karyawan di Universitas Nasional dapat membantu proses kenaikan golongan dan gaji dari yang sebelumnya masih menggunakan cara manual menjadi terkomputerisasi. Dengan demikian pendataan akan lebih 
baik dan dosen atau karyawan akan terbantu dengan aplikasi pengingat ini untuk mengajukan kenaikan golongan dan gaji tepat waktu.

2. Pengujian aplikasi dengan metode white box menunjukkan bahwa seluruh fungsi telah berjalan sesuai alur dan logika yang telah ditemtukan. Begitu juga dengan pengujian metode black box, output menunjukkan bahwa seluruh fitur dan fungsi berjalan dengan baik dan valid.

\section{DAFTAR PUSTAKA}

[1] Fakultas IImu Kesehatan Universitas Nasional, "Standar Operasional Prosedur: Pengajuan Kenaikan Pangkat/Golongan, Jabatan Fungsional," Jakarta, 2014.

[2] R. j Lena, S. Dengo, and J. M. Ruru, "Pengaruh Sistem Kenaikan Pangkat Terhadap Motivasi Kerja Pegawai Negeri Sipil Di Kantor Pertanahan Kota Sorong," J. Adm. Publik, vol. 3, no. 400, 2016.

[3] A. Fachry, S. Hadiyoso, and D. N. Ramadan, "Aplikasi Sistem Arsip Kepegawaian Untuk Keperluan Kenaikan Pangkat Dengan Pengingat Berbasis SMS Gateway (Studi Kasus Kantor Kecamatan Bojongloa Kidul Bandung)," e-Proceeding Appl. Sci., vol. 2, no. 1, pp. 367-374, 2016.
[4] E. R. Soktana, S. Ruliah, and R. Arnie, "Aplikasi Pendataan Dan Pengingat Kenaikan Gaji Serta Kenaikan Golongan Berbasis SMS Gateway," Progresif J. IIm. Komput., vol. 5, no. 2, 2016.

[5] Y. Prasetya, "Sistem Informasi Kenaikan Pangkat Dan Kenaikan Gaji Berkala Pegawai," Universitas Nusantara PGRI Kediri, 2018.

[6] H. Wijaya, "Sistem Aplikasi Pengingat Informasi Kepegawaian (APIK) Untuk Percepatan Pengusulan Kenaikan Pangkat Tepat Waktu dan Tepat Sasaran di Pemerintah Kabupaten Banjarnegara.," Banjarnegara, 2018.

[7] S. F. Latifah, "Rancang Bangun Sistem Informasi Kenaikan Pangkat Pada Kantor Gubernur Provinsi Nusa Tenggara Barat," Universitas Mataram, 2017.

[8] R. S. Pressman, Software Engineering: $A$ Practitioner's Approach 8e. New York: McGraw Hill, 2015.

[9] M. K. Hutauruk, "UML Diagram : Use Case Diagram," Binus University School of Computer Science, 2019. .

[10] M. E. Khan, "Different Approaches to Black Box Testing Technique for Finding Errors," Int. J. Softw. Eng. Appl., vol. 2, no. 4, 2011. 